\title{
AS DISJUNÇÕES COMO CHAVE PARA UMA INTERPRETAÇÃO DIALÉTICA DE ANGÚSTIA
}

Felipe Oliveira de Paula*

RESUMO: Com o objetivo de interpretar a formação da individualidade de Luís da Silva, narrador-personagem do romance Angústia (1936), analisei como ele se relaciona com os principais personagens e como eles se integram na realidade objetiva. Isso permitiu compreender como o protagonista foi desenvolvendo uma maneira própria disjuntiva, de apreender as contradições geradas pela dinâmica social. A disjunção, característica de sua personalidade, não se restringe, contudo, a sua visão de mundo mas é transposta na sua maneira de narrar e funciona também como princípio de organização interna na obra.

PALAVRAS-CHAVE: Narrador; personagem; narrativa *fopaula@yahoo.com.br Doutorando em Estudos Literários pela UFMG, e mestre pela mesma instituição.

ABSTRACT: In order to interpret the formation of Luis da Silva individuality, narrator-character of the novel Angústia (1936), analyzed as it relates to the main characters and how they integrate in objective reality. This allows us to understand how the protagonist was developing its own disjunctive, way to grasp the contradictions generated by social dynamics. The disjunction characteristic of his personality, not, however, restricts its worldview, but is implemented in the way of narrating and also works as a principle in the work of internal organization.

KEYWORDS: Narrator; character; narrative. 
O significado da palavra disjunção é "separar o que inicialmente está unido", e, nesse sentido, pode-se pensar uma leitura que leva em conta a existência de duas funções estruturais distintas quando se fala em Luís da Silva, protagonista do romance Angústia (1936): a do narrador e a do personagem. É possível analisar a mudança dos seus pontos de vista e, também, muito do que se manteve na sua personalidade desde sua fase infantil até a adulta como decorrentes dessa disjunção estrutural. Assim, estabelece-se certo tipo de deslocamento contínuo da visão de mundo do narrador em direção à do personagem, e vice-versa, o que provoca uma tensão constante entre os diferentes tempos e faz com que a função estrutural (narrador e personagem) esteja indissoluvelmente ligada à disjunção temporal (presente e passado). Ao mesmo tempo, a tentativa de utilizar o termo "disjunção" como uma possível chave interpretativa de Angústia não se restringe à aplicação do significado literal da palavra, pois, se assim o fosse, a análise não daria conta de acompanhar a dinâmica própria da narrativa, impedindo as flexões da matéria narrada. Por não se tratar de um romance chapado, não é possível utilizar um conceito fechado, mas exige-se um que brota a partir da leitura da obra. Pensando nisso, aplica-se "disjunção" não só como a separação do que está unido, mas, do mesmo modo, no seu movimento contrário e complementar, a junção do que se apresenta apartado. É nessa relação dialética entre desunir e integrar que o conceito é aqui empregado.
Percebe-se que há na narrativa de Luís da Silva uma espécie de encontro e desencontro permanente entre o personagem e o narrador, mas sua compreensão efetiva só é possíve caso eles sejam pensados na sua unidade. Não é recomendável interpretar o narrador sem o personagem, nem o contrário. É preciso, antes, o entendimento do personagem para se chegar ao narrador, e o do narrador para melhor conhecimento do personagem, isto é, o personagem e o narrador podem ser destacados um do outro para serem analisados, mas o entendimento de Luís da Silva e da narrativa de Angústia só se realiza de modo satisfatório caso vistos na sua totalidade. Dizendo de outra maneira, não é possível analisar o personagem e o narrador apenas como tais, isto é, apenas em sua configuração como personagem ou narrador. No caso de Angústia, a voz que expõe o personagem sofreu intimamente toda sua transformação existencial. Com efeito, em muitos casos, quando está lembrando e relatando sobre como era sua vida no passado, é possível distinguir o narrador do personagem mas essa distinção é interna, dá-se no próprio Luís da Silva, o que diferenciaria, e muito, da exposição de um narrador em terceira pessoa, mesmo se ele fosse onisciente e/ou onipresente, pois não teria vivido tais experiências e não seria afetado por elas, tal como foi Luís da Silva.

A preocupação não está em descrever algo de fora, com um olhar neutro em relação ao objeto, mas em instaurar 
uma perspectiva que nasce do objeto e se descola dele para tentar entendê-lo melhor. Ao contrário do romance em que o narrador está fora dos eventos narrados, existe aqui um narrador que está dentro e se coloca como personagem o tempo todo para, então, analisar sua condição. Institui-se, assim, uma perspectiva crítica do objeto, de tal modo que, ao retornar ao passado, Luís da Silva põe em prática um tipo de distanciamento com relação a ele mesmo, sem deixar de sê-lo. Isso não é específico do terceiro romance de Graciliano Ramos, mas a maneira de lidar sim, pois através da disjunção é possível, por exemplo, entender como Luís da Silva internaliza a passagem de uma sociedade tradiciona e agrícola, sustentada pelo latifúndio, para uma sociedade moderna, na qual se percebem várias modificações culturais e sociais aliadas à formação de uma burguesia industrial, mas que conserva o dinheiro como principal catalisador ético e moral. Com as disjunções narrador-personagem e presente-passado, captam-se os movimentos íntimos e históricos decorrentes da passagem da sociedade rural para a urbana, propiciando implementar na mesma realidade a coexistência de dois índices de tempo e de foco narrativo.

A partir disso, no primeiro momento, serão recuperadas as principais relações do personagem que podem ter desencadeado um modo disjuntivo na sua visão de mundo, para, logo depois, entender como a disjunção está incorporada na forma narrativa de Angústia.
BELO HORIZONTE

v. 20

\section{O SISTEMA DE RELAÇÕES DE LUÍS DA SILVA}

Para Luís da Silva, a realidade sempre se constitui numa ambivalência, e para que ele a compreendesse foi necessário desenvolver uma maneira própria de englobar os opostos, de modo que as diferentes atitudes e imagens de uma mesma pessoa não se anulassem ou se excluíssem, mas se complementassem, formando uma totalidade. Nesse sentido, a disjunção foi se tornando uma característica própria da personalidade de Luís da Silva. Para entender como ela foi sendo internalizada, é preciso compreender como os efeitos do desenvolvimento desigual de vários complexos sociais atuaram na subjetividade do personagem. Pois um conhecimento preciso de Luís da Silva pressupõe a noção tanto da propriedade específica do seu modo de ser como de suas ligações sociais. O desconhecimento da relação, de que a unidade do ser humano existe na diversidade, pode levar a uma falsa conclusão. Nesse raciocínio, a disjunção é uma caracterização que deve ser historicamente situada, não vista como algo abstrato ou isolado, já que ela só pode ser concebida através daquilo que ele se tornou no seio das relações mantidas ao longo de sua vida.

Com efeito, privilegiar o estudo da essência humana em detrimento da social, ou o contrário, significa uma clivagem do ser em espírito e corpo, o que promove uma observação da individualidade numa constituição bipartida do ser humano. Para evitar esse tipo de raciocínio, Luís da Silva é 
1. LUKÁCS, Prolegômenos para uma ontologia do ser social, p 80. pensado numa formação simultânea como um ser social e como um ser único. Usando livremente as ideias de Georg Lukács ${ }^{1}$, podemos dizer que Luís da Silva existe ao mesmo tempo como um exemplar do seu "gênero" e como uma subjetividade "singular". O personagem Luís da Silva pode ser visualizado como um exemplar do seu gênero ao se considerar que ele é neto de um aristocrata que no final do século XIX perdeu todo seu poder, e que, em decorrência disso, aconteceu uma mudança radical na estrutura de sua família. Essa transformação, advinda do fator econômico, pode ser reconhecida não só em Luís da Silva, mas em pessoas que viveram numa época de transição e não conseguiram continuar desfrutando dos privilégios até então concedidos à oligarquia rural.

Quanto a sua singularidade, é preciso pensar como ele internalizou essas modificações e lidou com toda essa reestruturação. Para isso, mostra-se importante a imagem do seu avô Trajano Pereira e a do seu pai, Camilo Pereira. Nascido e crescido num momento de transição histórica e familiar Luís da Silva costumava ouvir histórias de grandes feitos do velho Trajano e, ao mesmo tempo, convivia com ele destituído física e economicamente, o que despertou no personagem um sentimento paradoxal de pena e admiração. Luís da Silva viveu toda a sua infância e o início de sua adolescência presenciando uma maneira nova e conflituosa de a família
Silva se comportar socialmente, já que, depois das modificações sócio-históricas, sobretudo após a lei áurea (1888), tudo aquilo que era admirado por seu avô e por seu pai deixou de fazer parte da organização familiar; restaram apenas ruínas. Foi um período de grandes dificuldades e, junto, vieram problemas de adaptação ao novo estilo de vida, o que pode ser comprovado no fato de o avô não ter se acostumado com sua decadência e continuar se comportando como grande senhor; o que se comprova nas ocasiões em que ele ficava bêbado na Vila e só voltava para casa com a ajuda de seu ex-escravo, mestre Domingos. Camilo Pereira também agia como se a família continuasse fazendo parte da oligarquia rural e passava os dias curtindo sua preguiça na rede. Por tudo isso, o personagem principal vai se desenvolver num ambiente ambivalente de decadência e de orgulho por ter feito parte da classe abastada no passado. Não se pode negar que esse contexto vai ser um fator importante na formação da sua personalidade. Primeiro, porque a falência da família vai implicar diretamente nas suas condutas do cotidiano, visto que ele e o pai são obrigados a sair da fazenda à procura de melhores condições de sobrevivência na Vila. Segundo, porque todo esse ressentimento em relação à mudança de classe social vai ser uma constante na personalidade do protagonista, acompanhando-o durante a sua trajetória e produzindo nele recalques que culminarão no enforcamento de Julião Tavares. 
Assim, o que há de mais singular em Luís da Silva só pode ser identificado quando concretizado, em práticas ou em pensamento. Sua maneira própria de apreender o momento de mudança do regime monárquico para o republicano e a decadência da família, existindo ao mesmo tempo como "exemplar do gênero" e como "subjetividade singular", só pode vir à tona e ser realçada quando suas qualidades forem percebidas num processo de desenvolvimento essencialmente histórico. Em outras palavras, Luís da Silva não existia como se fosse um balão vazio que de repente se encheu, obtendo uma forma. Com movimentos próprios, a sua consciência e, por conseguinte, a sua individualidade foram paulatinamente sendo constituídas nas suas relações sociais, o que impede de pensá-las como desconexas da realidade em que vive. A modificação geral do mundo e sua própria modificação é que formam a subjetividade de Luís da Silva. Pensando no objetivo desta parte do trabalho, a assimilação da disjunção à sua visão de mundo também deve ser enxergada na dinâmica existente entre os complexos que compõem a sua totalidade, uma vez que toda modificação ou constituição é desencadeada por inter-relações reais.

Se, portanto, quisermos compreender de modo mais multilateral e objetivo possível o tornar-se indivíduo do homem, quisermos entender suas tentativas vitalmente necessárias de levar à unidade em si mesmo, as decisões isoladas altamente heterogêneas quer pelo conteúdo quer pela forma, como elementos dinâmicos da própria personalidade, só o poderemos fazer lembrando que nesse complexo sempre móvel, sempre processual, cada momento nasce de problemas sociais reais da respectiva fase da generidade, e, qualquer que seja a práxis em que se traduz, em última análise, da mesma forma nela desemboca. Portanto, é ontologicamente impossível apenas imaginar uma individualidade sem essa origem e esse desfecho, e muito menos ver, em seu ser isoladamente pensado, em seu - sob esta óptica: pretenso - movimento próprio, o princípio unificante, que realmente orienta a individualidade. (LUKÁCS, 2010, p. 100).

Diante disso, para captar uma característica própria do personagem Luís da Silva, mostra-se necessário ter em mente suas relações como elementos dinâmicos que atuam na sua personalidade (também dinâmica). Cada movimento geral é processado e incorporado a sua personalidade de maneira específica, promovendo uma percepção subjetiva dos acontecimentos. Novamente, para entender a complexidade desse sistema de relações, é preciso fazê-lo diante de problemas concretos, e, por se tratar de uma narrativa ficcional, privilegiou-se a configuração dos personagens mais significativos da trama.

O processo histórico é múltiplo e está em constante modificação, o que impulsiona os indivíduos a agirem de modo 
plural dentro de um mesmo contexto social. Segundo essa lógica, é inverossímil exigir dos personagens, que na narrativa estão todos situados historicamente, as mesmas atitudes diante de situações diversas. Assim, por exemplo, é inviável ao velho Trajano reagir nos seus últimos anos de vida tal como nos seus anos de glória. As situações se apresentam para ele sob ângulos diferentes: antes, podia resolver rapidamente seus problemas tendo como base seu poder de mando; depois de sua falência, tudo passou a ter outro significado e outra repercussão, já que o dinheiro não era mais sua base acrescentem-se a isso suas dificuldades físicas e mentais, as quais, por sua vez, o impossibilitaram de ter as mesmas percepções que tinha no tempo em que era grande senhor. Em suma, o movimento próprio da sociedade e a dinâmica do personagem fazem com que ele se configure na narrativa de maneira ambígua.

José Baía também é apresentado na narrativa com atitudes aparentemente contraditórias. Assim como o velho Trajano, não se pode entender sua caracterização desvinculada do processo de desenvolvimento do Nordeste brasileiro. José Baía é um cangaceiro hábil e oferece sua força de trabalho em troca de alimentação, moradia e proteção do avô do protagonista Aos poucos, o agregado foi se tornando grande amigo de Luís da Silva e nos intervalos do seu trabalho ficava proseando e contando histórias para o menino. Com efeito, percebe-se que sua função exige a divisão de sua vida em pelos menos duas partes: pública e privada ${ }^{2}$. A primeira relaciona-se ao seu papel dentro do sistema patriarcal brasileiro, sendo impelido a incrementar sua destreza e sua astúcia de cangaceiro para continuar exercendo com eficiência seu trabalho; e manter sua relação de cordialidade com Trajano. Disso resultou o respeito misturado a medo de todos a sua volta. Na segunda, ele exerce suas características extraídas do caráter subjetivo nas relações de amizade com Luís da Silva e com os moradores e frequentadores da fazenda. Novamente, percebe-se que a configuração desse personagem dentro da narrativa acompanha uma movimentação íntima e geral, sendo eliminada, por sua vez, sua interpretação como algo abstrato, visto que não se trata de uma criação imaginária de Luís da Silva.

Revela-se, assim, a importância e a influência do mundo senhorial na construção da individualidade do protagonista, pois, dentro dessa sociedade em transição, as duas pessoas mais próximas não se apresentavam de modo uniforme. Desde criança, Luís da Silva vai aos poucos constituindo um olhar capaz de apreender as contradições geradas pelo convívio social.

$\mathrm{Na}$ sua fase adulta, num ambiente citadino, a realidade não deixa de ser ambivalente, e, junto a essa dinâmica, as pessoas continuam agindo de forma plural e, muitas vezes, contraditória. Julião Tavares, por exemplo, como integrante 
da nova classe média, aproveita os privilégios de sua posição para desenvolver uma habilidade de se comunicar, para publicar seu livro e difundi-lo por todo o estado de Alagoas, e também para frequentar ambientes distintos. No entanto, a facilidade de se expressar se resume e se estagna numa loquacidade bacharelesca, formalizada num livro de poesia que exalta a "cor local" sem grande expressão e sem contribuir para o momento literário. Para o narrador, ele só consegue essa publicação devido à influência da família Tavares no meio jornalístico. O passaporte que tem para acessar diferentes espaços é aproveitado para se exibir e sustentar seu status social. O primeiro caso pode ser reconhecido no dia em que Luís da Silva o encontrou no Instituto Histórico colocando em prática sua linguagem verborrágica. No segundo, ele leva Marina para conhecer o teatro, uma maneira de demonstrar sua posição para ela e, em contrapartida, ostentar sua nova conquista para a sociedade. Ainda no segundo, percebe-se que ele frequenta a casa de Marina levando presentes luxuosos, deixando bem clara sua condição financeira e, logicamente, encurtando o caminho para conquistá-la Percebe-se também que sua inserção social é mediada por sua condição material, e todas as vantagens são utilizadas (com é típico de sua classe) apenas para o próprio bem-estar; tudo se restringe ao aproveitamento pessoal. Não faz parte de sua personalidade uma ética coletiva, isto é, ele não está preocupado em lançar um livro que realmente tenha importância e validade para a literatura local ou brasileira, o que ele quer é apenas recolher os elogios provenientes de sua publicação, para, assim, sustentar seu ego. Da mesma maneira, ele participa dos eventos culturais importando-se com o que eles podem trazer de satisfação pessoal. Isso se aplica às idas ao teatro, pois Julião Tavares pouco se importa com a peça, a dramatização, os atores, etc.; o que ele quer é ostentar sua presença no camarote da família. As idas à casa de Marina e o estreitamento das relações, também com Dona Adélia, não passavam de uma artimanha para seduzi-la. Tudo sempre tem um objetivo particular, e, para atingi-lo, ele não mede esforços.

A mesma lógica que rege essas práticas de Julião Tavares pode ser relacionada à que rege o sistema capitalista no plano econômico, visto que a preocupação maior do comerciante, como a da família Tavares, está em lucrar com tudo, independentemente dos meios aplicados para tanto. Para Eduardo Giannetti ${ }^{3}$, esse tipo de pensamento é uma constante no capitalismo moderno e é visto por alguns economistas como "caminho da prosperidade", já que partem da ideia de que quanto mais um indivíduo lucrar, melhor será para o sistema, pois, assim, ele estaria instigando uma competição, que, por sua vez, traria grandes proveitos para a sociedade. Esse tipo de conduta é classificado como "egoísmo ético", conceito que auxilia a entender Julião de Tavares, visto que
3. GIANNETTI, Vícios privados, benefícios públicos?, p. 160.

EM TESE $\quad$ BELO HORIZONTE $\quad$ v. $20 \quad$ N. $1 \quad$ JAN.-ABr. $2014 \quad$ PAULA. As disjunções como chave para uma interpretação dialética $[\ldots] \quad$ P. 149-168


suas práticas só acontecem quando há um objetivo pessoal a ser alcançado, como é típico do cidadão burguês no início do século XX. Assim, a configuração da ambiguidade do personagem Julião Tavares na narrativa é interpretada com clareza à medida que ele é pensado dentro de um sistema de relações concretas.

Do mesmo modo, a personagem Marina pode ser compreendida por diferente perspectiva quando posta dentro de um processo de desenvolvimento social. Proveniente de uma família muito pobre, ela sempre teve a ambição de se tornar uma pessoa com os privilégios da classe burguesa. Nesse sentido, ela inicialmente estreita sua relação com Luís da Silva pensando ser esse o melhor caminho. Contudo, quando conhece Julião Tavares, vê que Luís da Silva não passava de um "pobre coitado". Suas atitudes contrárias, de aceitar a proposta de casamento do seu vizinho e logo depois recusá-la fazem parte da lógica da personagem, que está socialmente situada; o que impede de pensá-la com algo dependente de Luís da Silva. Ela é integrante de uma sociedade que abarca e promove vários tipos de contradições sociais, de maneira que a verdade da personagem depende das complexas inter-relações sociais mantidas por ela ao longo de sua trajetória.

Diante do exposto, observa-se que os personagens não se mostram interessantes como um fenômeno social, não se procura neles somente "traços típico-sociais caracterológico-individuais definidos e rígidos, como imagem determinada, formada de traços monossignificativos e objetivos que, no seu conjunto, respondem à pergunta: 'quem é ele?"'4. Diferentemente, o que importa é como cada personagem se apresenta tendo vários pontos de vista sobre o mundo e sobre ele mesmo, como se posicionam em relação à realidade circundante. Nesse sentido, dizer que determinado personagem tem autonomia significa dizer que existem mecanismos e meios próprios para a sua configuração, mas integrados a uma totalidade cuja essência é múltipla.

A inserção de Luís da Silva nessa sociedade também é contraditória. Impossibilitado de se ajustar à classe endinheirada, ele realiza um trabalho improdutivo para ele mesmo, mas produtivo para a manutenção do modo de produção capitalista, já que ele é impelido a produzir e difundir uma ideologia que tem como objetivo conservar a exploração de que ele próprio é vítima. Isso fica claro no seu dilema em escrever artigos sobre livros literários de péssima qualidade, ou, no seu desempenho dentro da repartição, onde sua habilidade de escritor é restrita a escritos burocráticos e predefinidos. Este é, para Letícia Malard ${ }^{5}$, o fundamento da consciência contraditória de Luís da Silva como intelectual, visto que é burguês pela sua função ideológica, pequeno-burguês se se pensar sua posição social e, por fim, trabalhador assalariado pela sua situação econômica.
4. BAKHTIN, Problemas da poética de Dostoiévski, p. 52.
EM TESE v. 20
N. 1
5. MALARD, Ensaio de literatura brasileira, p. 22. 
6. LUKÁCS, Prolegômenos para uma ontologia do ser, p. 82
Diante de tudo isso, a lógica de Luís da Silva-personagem não pode ser interpretada separadamente das outras realidades que lhe dão vida e forma, pois a sua personalidade se constitui no sistema de relações. A subjetividade de Luís da Silva nasce exatamente do relacionar-se, de modo que é no contato com indivíduos distintos que sua particularidade vai sendo constituída. A partir de suas relações sociais, em contínuo desenvolvimento, ele cria sua própria maneira de viver "Esse processo, que se desenrola objetiva e subjetivamente, em constante interação entre objetividade e subjetividade faz surgir as bases ontológicas, das quais a singularidade do ser humano, ainda em muitos aspectos meramente natural, pode adquirir aos poucos caráter de individualidade (social, possível apenas na sociabilidade)"6. Tal pensamento corrobora a ideia de que a disjunção não é algo imposto, mas sim um elemento que foi se fazendo próprio na maneira de Luís da Silva ver o mundo. Iniciada na sua infância, ao pouco foi sendo depurada, numa constante interação entre mundo interior e exterior, até se tornar uma característica de Luís d Silva adulto. Por conseguinte, um modo próprio de entender o mundo e a si próprio.

\section{FORMA NARRATIVA}

O processo de formação da subjetividade do personagem-narrador de Angústia é deixado de lado por uma parte da crítica que se preocupou mais em relacionar o livro com a biografia do autor, privilegiando uma leitura que permitisse compreender a infância de Graciliano Ramos a partir da de Luís da Silva, e vice-versa; e também por pesquisadores que procuraram identificar até que ponto a revolta e o descontentamento do protagonista tinham relação com a personalidade do escritor. Muitos estudiosos constataram essa correlação e, em algum grau, conseguiram compreender certas atitudes de Luís da Silva ou de Graciliano Ramos. No entanto, diferentemente daqueles que utilizaram o presente e o passado do protagonista para aprofundar uma análise da vida de quem assina a obra, esta parte do trabalho visa a analisar a disjunção na forma narrativa, sem levar em conta características da vida empírica do velho Graça.

A disjunção é uma constituinte na subjetividade de Luís da Silva-personagem cuja configuração se deu na sua relação entre mundo interior e exterior. Esse processo de construção da personalidade é concebido não só na visão de mundo que apresenta, mas também no seu modo de narrar. Quando Luís da Silva-narrador expõe sua trajetória de vida, instaura-se uma forma disjuntiva na estrutura narrativa acompanhando uma dinâmica própria da sua consciência. A disjunção representa uma separação técnica entre personagem e narrador na mesma persona ficta, recurso que se mostra comum em romances escritos em primeira pessoa, como demonstra Franz Stanzel (1971). Nesses tipos de narrativa existe uma 
distância temporal e espacial que separa o fato ocorrido do momento da enunciação, provocando uma modificação no ponto de vista do protagonista, isto é, ocorre uma metamorfose existencial que the possibilita reorganizar e refletir sobre o acontecido, de modo tal que o narrador em primeira pessoa vê a si mesmo como personagem de sua própria história, sem, contudo, deixar de ser a mesma pessoa. Esse é um procedimento natural que pode ser percebido quando se coloca em prática a autorreflexão.

No caso de Angústia, a divisão estrutural está intimamente relacionada com o tempo da infância e da fase adulta. Não seria possível pensar Luís da Silva como personagem se o tempo se restringisse ao momento da enunciação. A narrativa por acompanhar o drama íntimo do narrador, estabelece um entrelaçamento dos dois tempos. Assim, a típica mudança de função estrutural que ocorre nas narrativas em primeira pessoa é configurada, aqui, de forma particular, por gerar um confronto entre os dois "eus", com nítida preferência ao eu de outrora. Esse processo de constante tensão constitui "um tempo novelístico muito mais rico e, diríamos, tríplice, pois cada fato apresenta ao menos três faces distintas: a sua realidade objetiva, a sua referência à experiência passada, a sua deformação por uma crispada visão subjetiva" ${ }^{7}$. Com efeito, Luís da Silva passa a colidir um mundo fantasioso e perfeito com um imediato e desajustado, o que, por sua vez, o permite cotejar a realidade em que vive, e como a vive. O resultado desses embates é o seu autoconhecimento, deixando mais evidente o que está obscuro na sua intimidade. Assim, a disjunção, oriunda da sua realidade, é expressa no seu modo de narrar e projeta um significado estrutural que propicia visualizar sua ilusão de unicidade. A ambiguidade tem correspondência na representação formal ao transferir para o interior da própria estrutura aquilo que efetivamente ocorre na ontologia do ser social. A situação narrativa se torna ambivalente quando Luís da Silva assume e privilegia a posição de narrador de sua própria vida, ao mesmo tempo que visualiza o eu-personagem como ele mesmo.

Nesse raciocínio, a narrativa de Luís da Silva é fragmentada exatamente para dar conta de expressar e representar uma realidade interior e uma exterior, cada uma delas, em si mesma, multifacetada. Caso o narrador tentasse contar sua história de maneira linear e cronológica, não seria possível identificar uma relação isomórfica com a heterogeneidade do sujeito dentro de uma sociedade em que tudo sucede de forma fracionada. Segundo essa lógica, pode-se entender por que o livro não é dividido em capítulos, mas em "segmentos" sem uma ordem sequencial. Dentro de um mesmo segmento, o narrador estabelece perspectivas desiguais e complementares sobre um único objeto, como fica claro na parte em que Luís da Silva tenta ter relação sexual com Marina, p. 113 . 
8. RAMOS, Angústia, p. 57

9. RAMOS, Angústia, p.19 mas, por ela não aceitar, decide apressar a data do casamento. Logo depois do fato, ele reflete sobre a figura da vizinha e, ainda no mesmo segmento, a vê como leviana e como pessoa sensível, ligada às cerimônias de casamento.

Decorre que cada segmento representa o modo de Luís da Silva enxergar o mundo e de se expressar; no entanto, a parte só tem sentido quando vista na arquitetura romanesca como integrante de um todo, ou seja, a totalidade da narrativa se faz no movimento das partes em tensão e conflitos muitas vezes contraditórios. Nessa dialética, a forma incorpora a descontinuidade presente na consciência do narrador, da mesma maneira que o processo social é indicado em sua incompletude, devido às descontínuas relações, subjetivas e objetivas. Por sua vez, tudo isso só acontece porque está em consonância com sua maneira de se expressar, pois suas opiniões, como ele próprio diz, "são fragmentadas, instáveis e numerosas"8. E, noutro momento, se caracteriza da seguinte maneira:

Lembro-me de um fato, de outro fato anterior ou posterior ao primeiro, mas os dois vêm juntos. $\mathrm{E}$ os tipos que evoco não têm relevo. Tudo empastado, confuso. Em seguida os dois acontecimentos se distanciam e entre eles nascem outros acontecimentos que vão crescendo até me darem sofrível noção de realidade. As feições das pessoas ganham nitidez. De toda aquela vida havia no meu espírito vagos indícios. ${ }^{9}$
Como notou Álvaro Lins ${ }^{10}$, toda a desordem aparente acontece porque Angústia é "consequência lógica e perfeita do estado de espírito do personagem-narrador". Nesse ponto, vale utilizar as palavras de Graciliano Ramos, como crítico de sua própria obra, para contrapor ao pensamento aqui desenvolvido; trata-se de uma carta direcionada a Antonio Candido como agradecimento pelos artigos sobre seus livros:

Angústia é um livro mal escrito. Foi isto que o desgraçou. Ao reeditá-lo, fiz uma leitura atenta e percebi os defeitos horríveis: muita repetição desnecessária, um divagar maluco em torno de coisinhas bestas, desequilíbrio, excessiva gordura enfim, as partes corruptíveis tão bem examinadas no seu terceiro artigo. É preciso dizermos isto e até exagerarmos as falhas: de outro modo o nosso trabalho seria inútil (CANDIDO, 2006, p. 10).

É justamente onde o escritor enxerga defeitos que o romance se mostra grandioso e bem engendrado. $\mathrm{O}$ que ele chama de "repetição desnecessária" e "gordura excessiva", provenientes das constantes voltas de Luís da Silva ao passado, às vezes demorando-se mais, às vezes menos, pode ser visto como a representação de uma peculiaridade de Luís da Silva. Assim, o movimento da narrativa é uma exigência da matéria e permite transformar essas idas e vindas no tempo em elemento formal. Ao ingressar na forma, a disjunção
10. LINS, Conteúdo e forma enriqueceram a literatura brasileira, p. 324.
EM TESE
BELO HORIZONTE
v. 20
N. 1
JAN-ABR. 2014
PAULA. As disjunções como chave para uma interpretação dialética [...] P. 149-168 
perde sua feição de realidade exclusivamente individual para se converter em elemento estruturante do livro. Caso ela se limitasse a Luís da Silva-personagem, seu reconhecimento se restringiria ao foco narrativo e ao plano temático, mas, a partir do momento em que se configura na narração, a disjunção pode ser visualizada também na forma. Isso acontece porque Luís da Silva-narrador transpõe sua visão de mundo na sua maneira de narrar, o que pode ser comprovado na interpretação dos personagens mais significativos da trama pois eles são expostos como pessoas de atitudes plurais e, às vezes, contraditórias. Não há uma preocupação em mostrar um lado de determinado personagem e depois outro, já que isso poderia acarretar num achatamento de uma realidade ambivalente, tornando a trama inverossímil. Essa relação entre forma e conteúdo faz com que cada coisa viva e atue sobre a outra.

A dinâmica própria da narrativa propicia conhecer muito de Luís da Silva e de suas relações, como a que teve com o pai. A imagem de Camilo Pereira só foi entendida com clareza depois de vários anos, quando Luís da Silva se propõe a refletir sobre sua vida, em razão do assassinato cometido. Ele nunca soube muito bem como lidar com o jeito do pai, só depois de muitos anos, quando está no presente remoendo toda a sua trajetória, é que consegue visualizar melhor a figura de Camilo Pereira e o que sentia na época.
Decorrem disso dois aspectos interligados. Primeiro, a disjunção temporal entre o personagem e o narrador permite que se instaure um olhar afastado do caso e faz com que seja eliminada parte da emoção do momento. Quando uma pessoa narra um acontecimento do qual fez parte logo após ele ter ocorrido, agregam-se à sua fala todos os sentimentos provocados pela situação, e, por questão lógica, a descrição estará comprometida por um ponto de vista mais parcial. Isso não quer dizer que a imparcialidade seja alcançada caso o relato seja feito após alguns anos, mas, com certeza, o passar do tempo promove um olhar mais distanciado. No espaço de tempo que separa o personagem do narrador, percebem-se um amadurecimento e um olhar mais "de fora", que o ajudam a entender as atitudes do pai e as suas próprias, principalmente quando Camilo Pereira morre.

Segundo, se, por um lado, a metamorfose existencial possibilita uma visão mais afastada e mais racional da sua infância, por outro, Luís da Silva-narrador, ao pôr em prática a autorrepresentação, não consegue ir além de uma recriação do que realmente sucedeu. Sua visão de mundo é própria de sua consciência do momento, de tal maneira que os fatos resgatados do passado dependem, sobretudo, do que está acontecendo no presente. Com efeito, ao recuperar a figura do pai e a do filho Luís da Silva, o que se obtém é o conhecimento (e não o reconhecimento) do objeto pensado, pois o 
11. SOUZA, Fichte e as questões de arte: a filosofia de Fichte e a poesia moderna, p. 144. sujeito pensante está em constante modificação e autogestação no que diz respeito ao seu passado ${ }^{11}$.

Assim, a disjunção temporal existente na narrativa de Luís da Silva permite um olhar mais distanciado do que aconteceu, propiciando ao narrador uma tomada de consciência em relação a suas atitudes praticadas na época passada, e, ao mesmo tempo, esse olhar afastado é comprometido pelo que ele está vivendo no momento atual. Pensando nisso, a figura do pai aparece na economia da narrativa para demonstrar o impacto negativo que teve na vida de Luís da Silva nos âmbitos financeiro e pessoal. Primeiro por causa de sua inércia diante da ruína que se instaurava na família Silva, revelando, assim, ser uma pessoa que nasceu como um típico aristocrata rural, mas que, devido à sua falta de habilidade para se organizar e se fortalecer diante das transformações históricas, morreu como pequeno-burguês, sem qualquer representatividade social e sem poder econômico. Isso afetou diretamente o modo de vida de Luís da Silva-personagem e, por consequência, Luís da Silva-narrador. Segundo porque a relação conflituosa entre o pai e o filho estimulou este a se habituar a um modo de vida retraído e isolado de tudo o que acontecia em sua volta. Ele não era autorizado a interagi com outros meninos da sua idade e sempre teve de viver em um mundo paralelo. O mundo das outras crianças só poderia ser conhecido pelo olhar, de longe:
Procurava fixar a atenção nas crianças que dançavam e corriam, como dançavam e corriam, na areia do Cavalo-Morto, os meus companheiros, alunos de mestre Antônio Justinho. Lá estava novamente entrando no passado, torcendo-me como parafuso. - "Rei meu senhor mandou dizer que fossem ao cemitério e trouxessem um osso de defunto". Quem tinha coragem? Os mais atrevidos chegavam até o muro de seu Honório, no fim da rua. Adiante o lugar era mal-assombrado e ninguém se aventurava por lá. Eu queria gritar e espojar-me na areia como os outros. Mas meu pai estava na esquina, conversando com Teotoninho Sabiá, e não consentia que me aproximasse das crianças, certamente receando que me corrompesse. Sempre brinquei só. Por isso cresci assim besta e mofino. ${ }^{12}$

Com a conclusão de que se tornara um adulto enfezado socialmente por causa das imposições do pai, é possível entender como a disjunção estrutural (personagem e narrador) e temporal (passado e presente) se mostra como uma forma de configuração que auxilia Luís da Silva a compreender melhor o seu modo de vida e a importância da figura de Camilo Pereira da Silva para a constituição de sua personalidade e, consequentemente, para sua visão de mundo.

O recurso técnico denominado disjunção também promove o entendimento do indivíduo Luís da Silva como um ser irremediavelmente arruinado pelas transformações sócio-históricas. Sua narrativa expõe seu "subconsciente

$\begin{array}{llllll}\text { EM TESE } & \text { BELO HORIZONTE } & \text { v. } 20 & \text { N. } 1 \quad \text { JAN.-ABR. } 2014 & \text { PAULA. As disjunções como chave para uma interpretação dialética }[\ldots] & \text { P. } 149-168\end{array}$


13. FACIOLI, Dettera: ilusão e verdade sobre a (im)possibilidade em alguns narradores de
Graciliano Ramos, p. 59.

14. RAMOS, Angústia, p.210 danificado pelo mundo, pelas relações sociais degradadas. O fundamento deste subconsciente é a ordem econômica"13. Luís da Silva sempre teve de lidar com a falta de dinheiro e, por causa disso, se refugiou, continuamente, nas recordações de um passado-não-vivido para tentar esquecer sua condição de pobre-diabo: "a minha pátria era a vila perdida no alto da serra, onde a chuva caía numa neblina que escondia tudo"14. Desde novo, ele sempre sonhou com um estilo de vida próximo daquele que tinha o avô antes de sua decadência. No entanto, com a morte do pai, teve de sair da zona rural para a zona urbana com a esperança de "ser alguém na vida”. Ao se mudar para a cidade do Rio de Janeiro, ele nada consegue e tem de pedir esmolas para poder se alimentar. Na sua juventude, quando retorna para a cidade de Maceió, vive como pensionista na casa de dona Aurora e começa a vender seus escritos para aumentar sua renda e arranjar um jeito de sair daquele lugar. Depois disso, ele se submete a trabalhos alienadores que privam sua capacidade de escritor de literatura, já que ele tem de elaborar textos encomendados para jornais com opiniões contrárias às suas. Por causa do grande surto de desemprego, derivado do alto número de pessoas que migraram do campo para as cidades grandes, o governo tentou amenizar a situação abrindo novas vagas em cargos públicos (GALVÃO, 1972). Tudo indica que fo nessa leva que Luís da Silva conseguiu empregar-se como funcionário na repartição do município de Maceió. Embora esse trabalho tenha lhe dado certa estabilidade financeira, ele continua sendo limitado no que se refere a sua aptidão literária, visto que seu serviço se encerra na elaboração e na correção de ofícios técnico-burocráticos. Para não ficar restrito ao ordenado que ganha na repartição, Luís da Silva sob encomendas, continua escrevendo para jornais. Por tudo isso, existe uma revolta consciente em Luís da Silva com sua situação de "níquel social", proveniente de sua capacidade de reflexão crítica sobre a realidade e da sua frustração por não conseguir realizar uma grande obra literária, tendo de utilizar suas habilidades de escritor para vangloriar romances com pouco valor artístico.

Desse modo, ele não consegue se sentir satisfeito com o estilo de vida que tem e, através de seus mergulhos no passado, percebe na sua personalidade uma impregnação de fracassos acumulados na sua trajetória de vida. No passado: da infância rural decadente. No presente: de burocrata e jornalista subserviente; de ex-noivo traído e abandonado; de matador malsucedido. Diante da impossibilidade de uma reação organizada e efetiva, e frente a um sentimento de impotência perante o contexto sociocultural e histórico em que vive, o mundo que se apresenta como ideal para o narrador é o do avô, construído por ele mesmo ao longo de sua vida. Esse retorno de Luís da Silva para dentro de si demonstra algo significativo, pois se trata de um descontentamento com a
EM TESE
BELO HORIZONTE
v. 20
N. 1
JAN.-ABR. 2014
PAULA. As disjunções como chave para uma interpretação dialética [ ...] $\quad$ P. 149-168 
15. LUKÁCS, Teoria do romance, p.119. realidade em que vive e de uma insatisfação com o que vê. Ele não consegue ver sentido na atualidade, consequentemente não nutre qualquer expectativa em relação ao coletivo. Diante dessa descrença e da falta de apoio na realidade exterior, ele tenta encontrar uma solução, ou mesmo um esconderijo, nos seus pensamentos, nas suas memórias, passando a se esquivar de qualquer luta. Cada vez mais, o protagonista se isola em si mesmo, atitude que pode ser entendida através da explicação de Georg Lukács sobre a relação entre forma romanesca e realidade social:

Isso porque a elevação da interioridade a um mundo totalmente independente não é um mero fato psicológico, mas um juízo de valor decisivo sobre a realidade: essa auto-suficiência da subjetividade é o seu mais desesperado gesto de defesa, a renúncia de toda a luta por sua realização no mundo exterior - uma luta encarada já a priori como inútil e somente como humilhação. ${ }^{15}$

Isso acontece com Luís da Silva por ele se sentir fracassado em tudo o que faz, o que o impulsiona a procurar certo tipo de realização na sua subjetividade. E quando ele se propõe a sair de sua condição de ilhado e tenta, por duas vezes, encarar seu problema pragmaticamente, nada consegue. Na primeira vez, porque Marina - que era uma maneir de se alinhar a normalidade social - prefere ficar com Julião
Tavares. Na segunda, quando mata seu rival, ele pratica um ato isolado, que só tem repercussão momentânea no seu próprio interior.

Todo esse descontentamento e essa inadaptação de Luís da Silva com o mundo em que vive, pode explicar, por sua vez, o ilhamento do sujeito em suas próprias experiências, representando esteticamente uma característica do romance moderno, conforme Walter Benjamim: "A matriz do romance é o indivíduo em sua solidão, [...] Escrever um romance significa descrever a existência humana, levando o incomensurável ao paroxismo" ${ }^{16}$

Para expressar e representar esteticamente Luís da Silva na sua subjetividade e numa fragmentação crescente dentro da sociedade brasileira, Graciliano Ramos utilizou-se de recursos próprios da literatura moderna, como o fluxo de consciência estruturado através do monólogo interior e da livre associação de ideias, em que as palavras não visam a um interlocutor e decorrem de uma necessidade própria. Vale enfatizar que o escritor não se apropriou das conquistas modernas por questões externas à narrativa. Se, por um lado, essas técnicas do romance procuram mostrar a desintegração total do conceito tradicional de individualidade com o mundo, por outro, de uma maneira sutil e engenhosa, as soluções literárias de vanguarda serviram, em Angústia, para esclarecer e tornar inteligível o efeito do processo de desenvolvimento
16. BENJAMIM, A crise do romance, p. 54 .
EM TESE v. 20

N. 1

JAN.-ABR. 2014

PAULA. As disjunções como chave para uma interpretação dialética [...] P. 149-168 
histórico na personalidade de Luís da Silva, autorizando a pensar o "eu" numa contínua modificação sem deixar de ser o mesmo, a despeito da multiplicidade mais surpreendente e caótica da experiência imediata.

Percebe-se que dois aspectos do eu são especialmente relevantes para esse tratamento literário. Primeiro, além da sucessão de impressões e ideias diferentes, o eu parece exibir uma tendência para a organização da dinâmica e da economia da trama, pois ele não se comporta apenas como um papagaio passivo que repete tudo, mas como um participante ativo. O narrador estrutura e interpreta o que vivenciou, mas ainda o faz de um ponto de vista da economia da narração, já que essa é uma característica de sua individualidade. No segundo aspecto, o eu é experimentado como ele e evidencia certa qualidade de continuidade. Dizendo de outra maneira, apesar da rápida sucessão dos distintos momentos temporais e mesmo com todas as transformações existenciais, o eu não é meramente um rótulo conveniente acrescentado a esses elementos temporais, mas uma "espécie de estrutura" que exibe continuidade e totalidade, das quais o narrador é diretamente consciente, ao se considerar a mesma pessoa durante toda a sua vida. Dessa maneira, Luís da Silva é mostrado

não apenas como um repositório de percepções e memórias, mas predominantemente como um centro de funções ati- vas, "auto-reguladoras". E são essas funções que servem para transmitir à própria pessoa e ao leitor o fato de que um certo conjunto de experiências "diferentes" exibe a qualidade de estrutura e unidade que nos capacita a afirmar pertencerem elas à mesma pessoa. Similarmente, a consciência da continuidade como um ingrediente essencial da identidade é, invariavelmente, parte do retrato literário. ${ }^{17}$

Nessa lógica interpretativa, a correlação entre esses aspectos do tempo e do eu pode surgir em dois contextos. Primeiro, dentro do fluxo temporal do presente especioso, no qual a aparência é ilusória e não corresponde à essência, exatamente por se restringir ao momento do presente. Isso poderia ocorrer, por exemplo, quando uma leitura que pretenda analisar a revolta e a indignação de Luís da Silva ficasse restrita a sua fase adulta, quando tudo isso acontece. Esse tipo de análise poderia chegar a conclusões errôneas, como a de que ele é uma pessoa que deseja e acredita numa revolução socialista, que ele é um anarquista ou um esquizofrênico. $\mathrm{O}$ segundo contexto diz respeito às relações que formam a estrutura da memória, ou o passado pessoal, de Luís da Silva. Se o estudo se limitasse ao passado e às memórias do personagem, não seria espantosa uma afirmação que o apontasse como um homem puramente nostálgico, sem entender que o motivo de suas demasiadas recordações deve ser explicado sobretudo, pela sua condição concreta atual. Sem escolher
17. MEYERHOFF, O tempo na literatura, p. 31-32. 
um ou outro contexto, é preciso, a partir do eu, trabalhar a interdependência dos dois contextos para visualizar a constituição de uma totalidade. Assim, tão importante quanto uma análise dos recursos técnicos empregados na narrativa é interpretar a sua dependência funcional com as duas unidades de tempos (passado e presente) e a relação de Luís da Silva com eles, isto é, como estão sendo utilizado e qual o seu significado para a narrativa.

Em toda a narrativa de Angústia, pode-se perceber a exposição da consciência de Luís da Silva através de práticas romanescas cujo uso fora intensificado pela literatura moderna, e o momento em que isso acontece com maior nitidez, alcançando seu grau máximo de complexidade, é nos segmentos que vão da perseguição ao estrangulamento de Julião Tavares. Nesse intervalo de tempo, o narrador descarrega as frustrações e humilhações sofridas ao longo de sua vida, realçando todo o sofrimento gerado pela falta de dinheiro e uma necessidade de eliminar seu rival e tudo o que ele representa. Para tanto, suas recordações lhe vêm à mente como fontes de inspiração, principalmente a figura de José Baía:

Sentir-me-ia miúdo e perturbado, os músculos se relaxariam, a coluna vertebral se inclinaria para a frente, ocupar-me-ia em meter nas calças a camisa entufada na barriga. Afastar-me-ia precipitadamente, como um bicho interior. Agora tudo mu- dava. Julião Tavares era uma sombra, sem olhos, sem boca, sem roupa, sombra que se dissipava na poeira da água. A minha raiva crescia, raiva de cangaceiro emboscado [...] José Baía vinha contar-me histórias no copiar, cantava mostrando os dentes tortos e muito brancos. Era bom e ria sempre. ${ }^{18}$

Nesse episódio, Luís da Silva está seguindo Julião Tavares, mas ainda não tomou coragem suficiente para executá-lo. Ele sabe que o assassinato não será suficiente para modificar sua vida, pois o ato não passará de uma atitude subjetiva, mas ele se sente obrigado a fazê-lo. "Estava ali forçado pela situação", como se existisse uma força interior o levando aquilo, mas, no fundo, ele não gostaria de chegar a aquele ponto. Através do fluxo de consciência, o conflito de Luís da Silva entre matar ou não o seu rival fica exposto, representando o que se passa na sua consciência naquele instante. No trecho citado o embate interior fica claro quando ele cria uma situação hipotética de como seria o encontro caso acontecesse durante o dia, com toda a movimentação e as luzes que uma cidade grande possui. Para a estruturação desse monólogo, os verbos foram empregados no futuro do pretérito do indicativo, sinalizando que tudo não saíra de sua consciência. Quando Luís da Silva não se prende ao plano da mera suposição e volta a pensar no momento de sua perseguição, ele reconhece ali uma grande oportunidade de se vingar de tudo o que simboliza Julião Tavares e sua classe; inclusive da capacidade 
do rival de conquistar mulheres por causa do lugar que ocupa Mais a frente, no mesmo segmento, esse impasse novamente vem à tona através de outro monólogo interior, deixando em evidência uma tensão constante entre duas opções de saída: assassinar o seu rival e se sobrepor a ele ou continuar tentando se adequar às normas e, novamente, se comportar como um subordinado, permitindo a Julião Tavares escapar.

Habituei a falar baixinho na presença dos chefes. Era preciso que alguma coisa prevenisse Julião Tavares e o afastasse dali. Ao mesmo tempo encolerizei-me por ele estar pejando o caminho, a desafiar-me. Então eu não era nada? Não bastavam as humilhações recebidas em público? No relógio oficial, nas ruas, nos cafés, virava-me as costas. Eu era um cachorro, um ninguém. - "É conveniente escrever um artigo, seu Luís." E eu escrevi. E pronto, nem muito obrigado. Um Julião Tavares me voltava as costas e me ignorava. Nas redações, na repartição, no bonde, eu era um trouxa, um infeliz, amarrado. Mas ali, na estrada deserta, voltar-me as costas como a um cachorro sem dentes! Não. Donde vinha aquela grandeza? Por que aquela segurança? Eu era um homem. Ali era um homem.

- Um homem, percebe? Um homem. ${ }^{19}$

Nota-se que a necessidade de eliminar seu rival surge não só por causa da indiferença e dos rebaixamentos feitos por Julião Tavares, mas também pelos tratamentos comumente recebidos "nas redações, na repartição, no bonde". Diante disso, é possível afirmar que todo esse desequilíbrio tem como base a inferioridade econômica e social de Luís da Silva, de modo que as técnicas modernas são utilizadas, aqui, para dar vida e expressão a um conflito sobretudo psicológico, gerado pelas frustrações e pela sua incapacidade de se integrar à ordem vigente.

Nesse sentido, são pertinentes as palavras de Nelson Coutinho (1978) ao dizer que Luís da Silva não pode, em momento algum, ser desligado da sua concreta realidade social, o que eleva o desespero e a impotência à condição de "realidades ônticas", ou seja, coloca em questão a natureza social do ser humano. Em Angústia, "não há uma mera reprodução naturalista de uma associação de ideias, dos mecanismos psíquicos de um homem onticamente isolado sem nenhuma relação orgânica com a realidade objetiva" ${ }^{20}$. Tampouco há uma busca, através do monólogo interior, da manifestação de alegorias abstratas e só aparentemente profundas. $\mathrm{O}$ tratamento literário procura deixar exposta uma disjunção em Luís da Silva e, por conseguinte, em sua narração, ao mesmo tempo que demonstra o desequilíbrio e a dissolução psíquica do personagem situados historicamente. A solidão e a derrota não são transformadas em metafísica condição humana, pois elas decorrem de condições subjetivas e objetivas, que, para o crítico materialista, derivam da
20. COUTINHO, Graciliano Ramos, p. 100.

EM TESE $\quad$ BELO HORIZONTE $\quad$ v. $20 \quad$ N. $1 \quad$ JAN.-ABr. $2014 \quad$ PAULA. As disjunções como chave para uma interpretação dialética $[\ldots] \quad$ P. 149-168


posição de classe dos tipos representados e da estrutura alienante do mundo em que vivem. As técnicas de "vanguarda" não são utilizadas com um fim em si mesmo. Ao contrário, elas são veículos importantes para tornar evidente a realidade interior e exterior de Luís da Silva numa relação dialética. Os recursos literários comumente utilizados para expressar e representar a subjetividade do narrador servem também como maneira de dramatizar como o desenvolvimento dos processos objetivos ocorridos no Brasil na virada do século XIX é internalizado no indivíduo.

Por tudo isso, utilizar a ideia "disjunção" como chave interpretativa não significa aplicá-la como um elemento formal que soma as partes, mas uma tentativa de abranger um processo de tensão constante entre os vários complexos que compõem a totalidade de Luís da Silva, assim como, por extensão, a sua narrativa. Com outras palavras, a visão de mundo de Luís da Silva, a função estrutural narrador-personagem, o imbricamento do passado-presente, a forma narrativa e a percepção estética do livro podem ser analisadas numa relação dialética quando se cria uma chave interpretativa que englobe a dinâmica própria da narrativa, que se estabelece muitas vezes contraditoriamente.

\section{REFERÊNCIAS}

BAKHTIN, Mikhail. Problemas da poética de Dostoiévski. Rio de Janeiro: Forense Universitária, 2010a.
BENJAMIN, Walter. A crise do romance. In: Magia e técnica, arte e política. São Paulo: Brasiliense, 1994.

CANDIDO, Antonio. Ficção e confissão. Rio de Janeiro: Ouro sobre Azul, 2006a.

COUTINHO, Carlos Nelson. Graciliano Ramos. In: BRAYNER, Sônia (Org.). Graciliano Ramos. Rio de Janeiro: Civilização Brasileira, 1978. p. 73-122.

FACIOLI, Valentim. Dettera: ilusão e verdade sobre a (im) possibilidade em alguns narradores de Graciliano Ramos. Revista do Instituto de Estudos Brasileiros, São Paulo: IEB/USP, n. 35 p.43-68, 1993.

GALVÃO, Walnice Nogueira. As formas do falso: um estudo sobre a ambiguidade no Grande Sertão: veredas. São Paulo: Perspectiva, 1972.

GIANNETTI, Eduardo. Vícios privados, benefícios públicos? A ética na riqueza das nações. São Paulo: Companhia das Letras, 2007.

GOLDMANN, Lucien. A reificação. In: Rio de Janeiro: Paz e Terra, 1979. p. 105-152.

LINS, Álvaro. Conteúdo e forma enriqueceram a literatura brasileira. In: RAMOS, Graciliano. Angústia. (75 anos). Incluso Fortuna Crítica, organizada por Elizabeth Ramos. Rio de Janeiro: São Paulo: Record, 2011. p. 322-325.

LUKÁCS, Georg. A teoria do romance: um ensaio históricofilosófico sobre as formas da grande épica. São Paulo: Duas Cidades; Editora 34, 2000. 
LUKÁCS, Georg. Prolegômenos para uma ontologia do ser

questões de princípios para uma ontologia hoje tornada possível.

São Paulo: Boitempo, 2010.

MALARD, Letícia. Ensaio de literatura brasileira: ideologia e realidade em Graciliano Ramos. Belo Horizonte: Itatiaia, 1976.

MEYERHOFF, Hans. O tempo na literatura. São Paulo: McGrawHill do Brasil, 1976.

RAMOS, Graciliano. Angústia. 61. ed. Rio de Janeiro; São Paulo: Record, 2005

SOUZA, Ronaldes de Melo. Fichte e as questões da arte: a

filosofia de Fichte e a poesia moderna. In: CASTRO, Manuel

Antônio (Org.). A arte em questão: as questões da arte. Rio de

Janeiro: 7 Letras, 2005, p. 126-157.

\section{STANZEL, Franz. Narrative situations in the novel: Tom Jones,}

Moby-Dick, The Ambassador, Ulysses. Bloomington; London:

Indiana University Press, 1971 